\title{
Pengembangan Usaha Kecil dan Menengah
}

\author{
Heru Pramana* \\ Abdul Hakim **
}

\begin{abstract}
This paper analyzes factors that influence the development of micro, small and medium enterprises (MSME) in Indonesia. The variables used in this paper are gross domestic product, bank lending, and labor force. The tools to analyze the problem are the error correction model of Engle and Granger (1987), and the data used for estimation are time-series annual data from 1989-2009. The data analysis shows that all variables in the model significantly influence the number of such enterprises, both in the short run and in the long run.
\end{abstract}

Keywords : Gross domestic product, bank lending, labor force, MSME, error correction model

\section{Pendahuluan}

Usaha Mikro Kecil dan Menengah (UMKM) merupakan kelompok usaha terbesar di Indonesia. Kelompok ini telah terbukti mampu menjadi industri pengaman di tengah terpaan krisis ekonomi dan moneter (lihat misalnya Hafsah, 2004). UMKM, berdasarkan UU No. 28 tahun 2008, dikategorikan menjadi usaha mikro, kecil, dan menengah. Peningkatan kegiatan usaha sektor ini menjadi pẹnyeimbang di tengah proses restrukturisasi sektor korporat dan BUMN yang berlangsung lamban (Munizu, 2010).

UMKM mampu meningkatkan pendapatan nasional. Usaha mikro dalam penciptaan produk domestik bruto menurut lapangan usaha pada tahun 2008 adalah Rp 1.505 triliun atau 32,05\%, usaha kecil Rp 473 triliun atau 10,08\%. Untuk tahun tahun 2009, kontribusi UMKM untuk PDB 55\% diterima dari usaha kecil dan mikro. Berdasarkan survei dan perhitungan BPS, kontribusi terhadap PDB (non migas) adalah 62,71 persen pada tahun 1997 dan 63,89 persen pada tahun 2002. Peningkatan penerimaan PDB yang disebabkan peningkatan jumlah UMKM

- Alumni Fakultas Ekonomi UII

* Dosen Fakuitas Ekonomi UII 
mendekati puncak dalam 5 tahun terakhir. Pada tahun 2009 tercatat penerimaan PDB sebesar 5.613.441.70, dimana nilai tambah barang dan jasa yang dihitung menggunakan harga berlaku berada pada tingkat tertinggi dibandingkan tahun 2000 hanya menyentuh angka 1.264.918.7. Untuk diskusi lebih lanjut tentang peran UMKM dalam pembentukan PDB, silahkan baca Hafsah (2004).

Jumlah unit UKM pada beberapa tahun terakhir juga mengalami peningkatan rata-rata 9,5 persen per tahun. Pada tahun 2002 tercatat 38,7 juta dan pada tahun 2004 tercatat 42,4 juta unit usaha. Peningkatan jumlah unit usaha ini juga diikuti dengan kenaikan jumlah angkatan kerja di sektor UKM, tercatat hampir 80 juta orang, dan dari jumlah tersebut sebanyak 70,3 juta di antaranya bekerja pada sektor usaha kecil dan mikro.

Tabel 1.

Data tentang PDB, Kredit Modal Kerja, Angkatan Kerja, dan UMKM

\begin{tabular}{ccccc}
\hline Tahun & PDB & $\begin{array}{c}\text { Kredit Modal } \\
\text { Kerja }\end{array}$ & Angkatan Kerja & Jumlah UKM \\
\hline 1989 & 188432.9 & 63606 & 76234442 & 1978599 \\
1990 & 195597.2 & 97696 & 77802264 & 2113467 \\
1991 & 227502.3 & 113609 & 78433548 & 2473665 \\
1992 & 260786.3 & 122918 & 78518372 & 2476559 \\
1993 & 290532.5 & 150271 & 78412541 & 2478549 \\
1994 & 399564.7 & 188880 & 79762421 & 2524934 \\
1995 & 454514.1 & 234611 & 80110060 & 2585594 \\
1996 & 532630.8 & 292921 & 85701813 & 2730150 \\
1997 & 625505.9 & 378139 & 87049756 & 2851862 \\
1998 & 989573.1 & 487426 & 87672449 & 2196899 \\
1999 & 1009731.6 & 225133 & 88816859 & 2516275 \\
2000 & 1264918.7 & 269000 & 89837730 & 2598704 \\
2001 & 1449398.1 & 307594 & 90807417 & 2538283 \\
2002 & 1610011.6 & 365410 & 91647166 & 2711202 \\
2003 & 2013675.0 & 229514 & 90784917 & 2927978 \\
2004 & 2295826.2 & 282947 & 93722036 & 2671660 \\
2005 & 2774281.1 & 353613 & 93958387 & 2916025 \\
2006 & 3339216.8 & 415003 & 95456935 & 3194461 \\
2007 & 3950893.2 & 529058 & 99930217 & 3218597 \\
2008 & 4951356.7 & 680972 & 102552750 & 5399873 \\
2009 & 5613441.7 & 701164 & 104870663 & 6555756 \\
\hline
\end{tabular}

Keterangan: (1) $\mathrm{PDB}=$ Produk Domestik Bruto atas dasar harga berlaku menurut 
Lapangan Usaha (Rp Miliar). (2) Modal = Posisi Kredit Modal Kerja Perbankan Ménurut Sektor Ekonomi. (3) Angkatan Kerja = Penduduk 15 Tahun atau lebih yang bekerja menurut lapangan pekerjaan utama. UKM = total jumlah perusahaan industri rumah tangga (Mikro) dan Kecil (Juta unit)

Sumber: Badan Pusat Statistik, Statstik Indonesia, beberapa tahun terbitan.

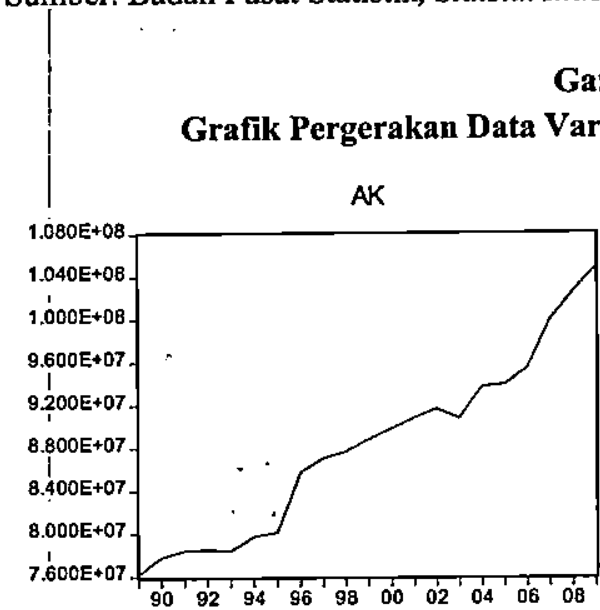

Gambar 1.

Grafik Pergerakan Data Variabel Terikat dan Variabel Bebas
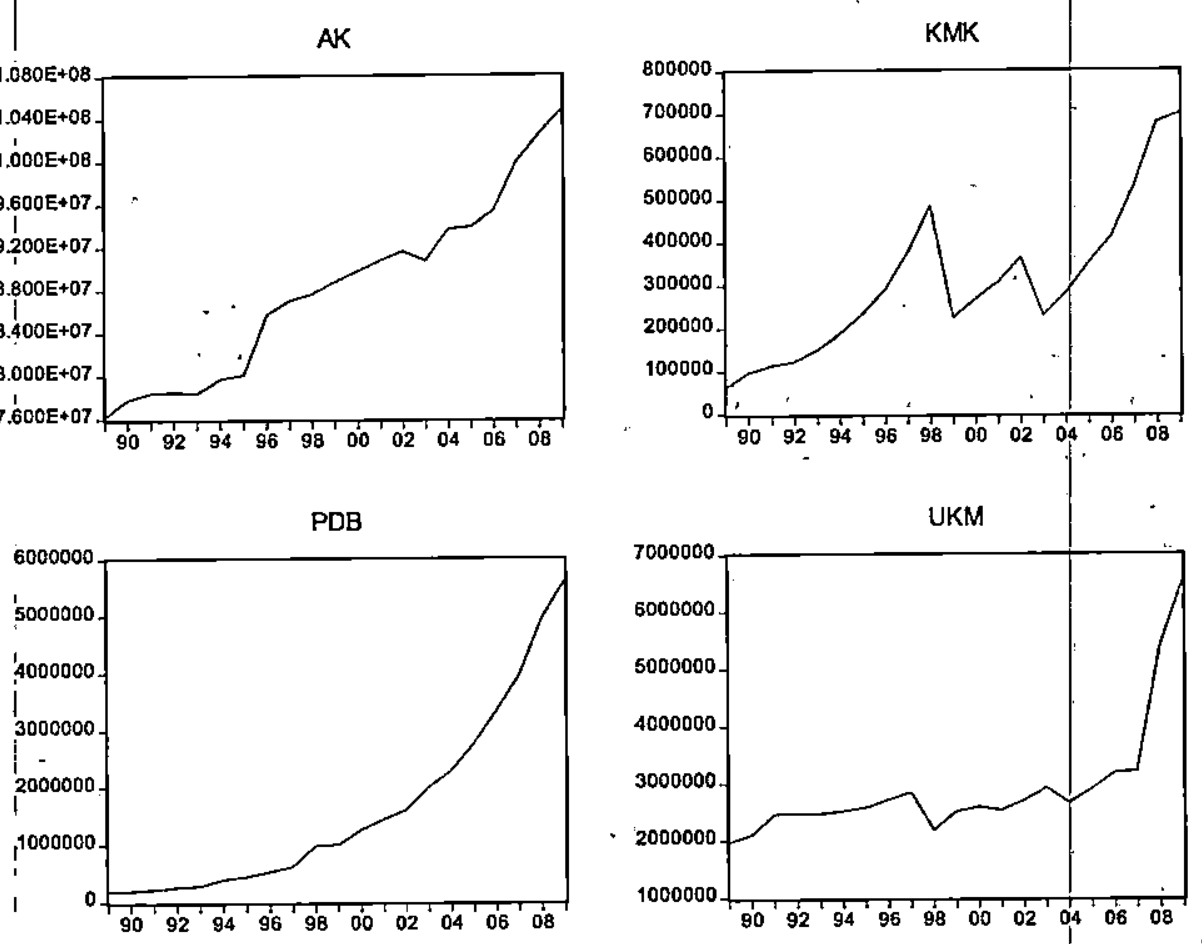

Sumber: Data Diolah

Peningkatan jumlah UMKM membuka banyak kesempatan kerja. Pada Agustus 2008 jumlah angkatan kerja mencapai 119,9 juta orang, meningkat 2 juta orang dibandingkan kondisi Agustus 2007 sebesar 109,9 juta orang. Jenis unit-unit usaha kecil dan rumah tangga seperti pertanian, industri pengelolaan rumahan, restoran dan perhotelan berperan dalam membuka kesempatan kerja yang sebesarbesarnya. Sering dikatakan bahwa di negara-negara yang sedang berkembang daya serap terhadap tenaga kerja tidak memadai, artinya dalam hal ini pertambahan jumlah tenaga kerja ada dalam persentase yang mampu memperoleh pekerjaan industri besar. Sementara itu, sisanya dengan terpaksa akan menerima pekerja dengan produktivitas rendah, terutama di sektor pertanian dan jasa (Sakernas 2007). 
UMKM juga menambah penciptaan lapangan kerja. Pada tahun 2009 tercatat 104.870.663 angkatan kerja dimana terjadi peningkatan signifikan dibandingkan tahun 1990 sebesar 77.802.264 yang mana tahun tersebut Indonesia mengalami keterpurukan ekonomi.

$\therefore$ Pertumbuhan UKM sangat dipengaruhi oleh industri perbankan. Peranan bank dalam penyaluran kredit adalah menambah modal dalam masyarakat yang membutuhkan dana dalam rangka memperkuat struktur permodalannya. Yang perlu didahulukan oleh bank adalah memperbaiki produk bank itu sendiri seperti giro, deposito, tabungan dan tingkat suku bunga pinjaman atau kredit yang bersaing. Hal lain yang perlu dilakukan adalah menyediakan modal dengan pola kemitraan untuk pemberdayaan potensi pelaku usaha. Kredit yang diberikan oleh bank kepada UMKM adalah Rp 104.870 .663 pada tahun 2009 yang jauh meningkat dibandingkan tahun 2000 sebesar Rp 89.837.730.

Melihat arti penting UMKM dalam sebuah perekonomian Indonesia, paper ini memodelkan perilaku pertumbuhan UMKM di Indonesia. Faktor-faktor yang diduga menjadi penjelas perilaku tersebut adalah PDB, angkatan kerja, dan kredit modal kerja. Untuk bisa membuat model yang baik, pertama kali akan kita definisikan berbagai' varibel terkait, baik variabel dependen maupun variabel independen.

Menteri Negara Koperasi dan Usaha Kecil dan Menengah mendefinisikan usaha kecil (UK), termasuk usaha mikro (UM), sebagai suatu usaha milik Negara Indonesia, baik perorangan atau berbadan hukum yang memiliki kekayaan bersih, tidak termasuk tanah dan bangunan sebanyak-banyaknya Rp 200 juta dan usaha tersebut berdiri sendiri. Bank Indonesia dan Departemen Perindustrian melalui surat Keputusan Menteri Perindustrian No.286/M/SK/10/1089, mendefinisikan usaha kecil adalah usaha yang jumlah assetnya, tidak termasuk tanah dan bangunan tempat usaha, bernilai kurang dari Rp 600 juta. BPS menggolongkan perusahaan dengan tenaga kerja 1-4 orang sebagai industri kerajinan dan rumah tangga. Perusahaan dengan tenaga kerja 20 sampai dengan 99 orang sebagai industri sedang atau menengah, dan perusahaan dengan tenaga kerja lebih dari 100 orang dikategorikan sebagai industri besar. UU No. 20 Tahun 2008 tentang UMKM mendefinisikan UMKM berdasarkan berbaga kriteria. Kelompok usaha mikro adalah usaha milik orang perseorangan yang memenuhi kriteria usaha mikro sebagaimana diatur dalam Undang-Undang ini. Kriteria usaha kecil adalah usaha ekonomi produktif yang berdiri sendiri, yang dilakukan oleh orang persorang atau badan usaha yang bukan merupakan anak perusahaan atau bukan anak cabang perusahaan yang dimiliki, dikuasai, menjadi bagian baik langsung maupun tidak langsungdari usaha menengah atau besar yang memenuhi kriteria usała kecil sebagaimana dimaksud dalam Undang-Undang ini. Kriteria usaha menengah adalah usaha ekonomi produktif yang berdiri sendiri, yang dilakukan oleh orang 
perseorangan atau badan usaha yang bukan merupakan anak perusahaan, cabang perusahaan yang dimiliki, dikuasai, atau menjadi bagian baik langsung maupun tidak langsung dengan usaha kecil atau usaha besar dengan jumlah kekayaan bersih dan hasil penjualan tahunan sebagaimana diatur dalam Undang-Undang.

PDB merupakan salah satu indikator perkembangan ekonomi suatu negara.

Pada umumnya perbandingan antar negara dapat dilihat dari pendapatan nasionalnya. Bank Dunia mengelompokkan negara ke dalam kelompok negara maju dan kelompok negara berkembang berdasarkan PDB yang masing-masing negara (Herlambang, 2001, hal. 26).

Kredit modal kerja adalah kredit yang diberikan oleh bank umum kepada debiturnya untuk memenuhi kebutuhan modal kerjanya. Modal kerja adalah kebutuhan modal yang habis dalam suatu siklus usaha. Dari neraca suatu perusahaan, modal kerja merupakan uang kas ditambah dengan piutang dagang ditambah persediaan barang jadi, persediaan bahan proses, persediaan bahan baku. Selanjutnya, modal kerja bersih adalah modal kerja dikurangi current liabilitasinya. Kredit menurut UU No.7 tahun 1992 pasal 1 butir adalah penyediaan uang atau tagihan yang dapat dipersamakan dengan itu, berdasarkan persetujuan atau kesepakatan pinjam-meminjam antara bank dengan pihak lain yang mewajibkan pihak peminjam untuk melunasi utangnya setelah jangka waktu tertentu dengan jumlah bunga, imbalan atau pembagian hasil keuntungan. Menurut Bank Indonesia, kredit modal kerja adalah kredit yang dipergunakan untuk menambah modal kerja untuk membiayai pembelian bahan baku, biaya produksi, biaya pemasaran, dan lain-lain dalam jangka pendek, biasanya satu tahun. Sebagai informasi tambahan, Bank Indonesia mendefinisikan kredit investasi sebagai kredit jangka menengah atau jangka panjang untuk pembelian barang-barang modal beserta jasa yang diperlukan untuk rehabilitasi, modernisasi, maupun ekspansi proyek yang sudah ada maupun pendirian proyek baru.

Angkatan kerja adalah penduduk usia produktif, yakni antara 15 sampai dengan 64 tahun yang sudah mempunyai pekerjaan tetapi sementara tidak bekerja, maupun yang sedang aktif mencari kerja. Angkatan kerja menurut BPS yaitu mereka yang selama seminggu yang lalu sebelum waktu pencacahan mempunyai pekerjaan. Angkatan kerja dikelompokkan menjadi empat golongan, yaitu (1) mereka yang bekerja penuh adalah angkatan kerja yang aktif menyumbang tenaganya dalam kegiatan produksi. (2) Pengganguran terbuka (open unemployment) adalah mereka yang sama sekali tidak bekerja, tetapi sedang mencari pekerjaan dan sewaktu-waktu siap bekerja. (3) Setengah menganggur (under unemployment) merupakan mereka yang bekerja tidak sesuai dengan pendidikan, keahliannya atau tidak menggunakan sepenuh tenaganya karena kekurangan lapangan pekerjaan. (4) Pengganguran tersamar (disguise unemployment), yakni pekerja yang tidak memberikan hasil yang optimal. 
Angkatan kerja menurut definisi Payaman Simanjuntak adalah sumber daya manusia yang mengandung dua pengertian. (1) Pengertian usaha kerja atau jasa yang dapat diberikan dalam proses produksi. Dalam hal ini sumber daya manusia mencerminkan kualitas usaha yang diberikan seseorang dalam waktu tertentu untuk menghasilkan barang dan jasa. (2) Sumber daya manusia yang mampu bekerja untuk memberikan jasa atau usaha jasa tersebut. Mampu bekerja berarti dapat melakukan kegiatan yang menghasilkan nilai ekonomis, yaitu bahwa kegiatan tersebut dapat memproduksi barang dan jasa untuk memenuhi kebutuhan masyarakat.

\section{Kajian Pustaka}

Sebagian besar penelitian tentang UMKM hanya menganalisis profil, peran dan masalah yang dihadapi UMKM. Misalnya, Hafsah (2004) menyimpulkan bahwa UKM mempunyai peran strategis dalam pembangunan ekonomi nasional dan penyerapan tenaga kerja. Tejasari (2008) juga mendapatkan kesimpulan yang mirip, yakni bahwa UKM dapat membuktikan bahwa sektor ini dapat menjadi tumpuan bagi perekonomian nasional.

Sebagian penelitian yang lain menganalisis pengaruh pemberian kredit ke UMKMM, tetapi melihat dampaknya pada kinerja UMKM. Sebagai contoh, Sebstad dan Chen (1996) melakukan survei atas berbagai studi yang menganalisis pengaruh pemberian kredit ke perusahaan kecil. Mereka menemukan bahwa sejak 1990, banyak studi atas topik tersebut yang menggunakan quasi-experimental designs dalam upaya memisahkan pengaruh kredit dari pengaruh faktor yang lain. Sebagian studi yang lain menggunakan campuran antara pendekatan kuantitatif dan kualititif. Mereka juga menemukan keterbatasan studi kuantitatif untuk mengungkap permasalahan dalam studi ini. Secara umum, mereka menemukan bahwa penganuh kredit atas output sebuah perusahaan adalah positif sedangkan pengaruh kredit atas pendapatan perusahaan adalah positif. Pengaruh kredit tersebut atas pertumbuhan sebuah perusahaan bervariasi. Namun studi ini tidak mengungkap pengaruh pemberian kredit terhadap jumlah usaha kecil dalam sebuah perekonomian.

Ada juga penelitian yang menganalisis pengaruh pemberian kredit ke UMKM, tetapi melihat dampaknya pada variabel makroekonomi seperti pengentasan kemiskinan. Pengaruh kredit modal kerja terhadap pertumbuhan ekonomi telah dilakukan oleh Wadud (2004) yang menemukan bahwa kredit modal kerja berpengaruh positif dan signifikan terhadap pertumbuhan ekonomi.

Hanya sebagian kecil penelitian yang menganalisis pengaruh pemberian kredit ke UMKM terhadap jumlah UMKM di sebuah perekonomian. Beberapa di antaranya adalah berikut ini. Lestari (2007) meneiliti strategi pengembangan dan pembiayaan usaha mikro kecil dan menengah di Indonesia. Dia menyimpulkan 
bahwa perkembangan dan prospek UMKM dipengaruhi oleh komitmen pemerintah untuk mengimplementasikan kebijakan-kebijakan yang berpihak terhadap pelaku usáha itu sendiri, seperti mempermudah proses administrasi dengan satu pintu khususnya yang berkaitan dengan hukum, memberikan akses informasi yang seluas-luasnya guna mempermudah pelaku usaha, serta mengajak lembaga keuangan perbankan dan bank Indonesia menjadi stakeholder dalam hal penyediaan dana kredit dimana pemerintah menjadi penjamin atau pihak ketiga.

Permadi (2009) menganalisis Pengaruh Total Kredit, PDB, dan Tingkat Suku Bunga terhadap Perkembangan Jumlah Unit Usaha Berskala Kecil dan Menengah (UKM) dengan menggunakan data time series dengan model kualitatif dan kuantitatif regresi linier biasa. Dia menemukan bahwa variabel total kredit dan PDB mempunyai pengaruh yang berbanding lurus terhadap peningkatan jumlah unit usaha berskala kecil dan menengah, sedangkan tingkat suku bunga yang berbanding terbalik dengan peningkatan jumlah unit usaha berskala kecil dan menengah. Variabel tingkat suku bunga berpengaruh sangat dominan terhadap peningkatan jumlah unit usaha berskala kecil dan menengah. Sriyana (2010) menganalisis strategi pengembangan usaha kecil dan menengah di Kabupaten Bantul, dan menemukan bahwa diperlukan regulasi dari pemerintah untuk memberikan peluang berkembangnya UKM melalui pembukaan akses perbankan yang lebih besar.

Tim Studi Departemen Keuangan RI (2011) memetakan potensi perusahaan UKM di Indonesia untuk go public dan membahas masalah dan hambatan yang dihadapi perusahaan UKM dalam proses go public. Tim menyimpulkan bahwa terdapat sekitar $40 \%$ perusahaan UKM dari 15 propinsi di Indonesia yang berpotensi masuk pasar modal. Hasil survei lain juga menyimpulkan bahwa potensi perkembangan UKM Indonesia tergolong tertinggi diantaranya karena kemudahan mendapat akses pembiayaan dan kebutuhan pembiayaan UKM yang tinggi.

Dari berbagai penelitian tersebut, tampak bahwa pengaruh pemberian kredit kepada UMKM terhadap pertumbuhan jumlah UMKM belum banyak dibahas. Túlisan ini dimaksudkan untuk mengisi gap tersebut.

\section{Metode Penelitian}

Untuk menganalisis perilaku variabel jumlah UKM di Indonesia, penelitian ini memasukkan tiga variabel penjelas, yaitu PDB, kredit modal kerja, dan angkatan kerja. Untuk setiap jenis variabel, data time series tersedia sebanyak 21 observasi (1989-2009).

Data jumlah UMKM diperoleh dari buku statistik Indonesia dalam angka berbagai tahun penerbitan yang diterbitkan oleh BPS. Data PDB dalam penelitian 
ini diperoleh dari buku Statistik Indonesia Dalam Angka berbagai tahun terbitan yang diterbitkan oleh Badan Pusat Statistik Indonesia.

Kredit modal kerja adalah kredit yang terdapat dalam neraca sebelah debit, sedangkan yang dimaksud dengan barang-barang modal ialah semua barang yang ada dalam rumah tangga perusahaan dalam fungsi produktifnya untuk membentuk pendapatan (Rp juta per tahun) dengan tahun dasar 1989 sampai 2009. Data tersebut diperoleh dari Statistik Keuangan sektor Posisi kredit modal kerja persektor ekonomi diterbitkan oleh BPS.

Angkatan kerja adalah penduduk usia produktif yang selama seminggu lalu sebelum waktu pencacahan mempunyai pekerjaan. Data angkatan kerja dalam penelitian ini diperoleh dari Statistik Ketenagakerjaan sektor penduduk 15 tahun keatas menurut status pekerjaan utama diterbitkan oleh BPS dalam berbagai tahun penerbitan.

\section{Error Correction Model (ECM)}

Penelitian ini menggunakan analisis regresi dengan model dinamis, yaitu dengan menggunakan error correction model (ECM). ECM digunakan untuk mengetahui pengaruh jangka pendek dan jangka panjang variabel independen terhadap variabel dependen. Teknik terbaik untuk mengkoreksi ketidakseimbangan jangka pendek menuju keseimbangan jangka panjang serta dapat menjelaskan hubungan antara variabel dependen dengan variabel independen pada waktu sekarang dan waktu lampau. Penggunaan model dinamis bisa menghindarkan masalah . regresi lancung (spurious regression) yang bisa berujung pada biased estimation. Akibat yang ditimbulkan oleh suatu regresi lancung antara lain koefisien regresi penaksir tidak efisien, peramalan berdasarkan regresi tersebut akan meleset dan uji baku yang umum untuk koefisien regresi menjadi tidak sahih (untuk kepustakaan, baca misalnya Engle dan Granger, 1987).

Salah satu kondisi yang harus dipenuhi supaya terhindar dari spurious regression adalah bahwa data yang digunakan harus stasioner. Konsep yang berhubungan erat dengan model dinamis adalah kointegrasi, yakni hubungan keseimbangan jangka panjang antara variabel-variabel yang tidak stasioner. Untuk menguji keberadaan kointegrasi tersebut, penelitian ini menggunakan metode Engle-Granger cointegration test.

Untuk kasus dalam penelitian ini, jumlah UMKM merupakan fungsi dari PDB, kredit modal kerja, dan angkatan kerja, atau

$$
U M K M_{i}=b_{0}+b_{1} P D B_{i}+b_{2} K M K_{i}+b_{3} A K_{i}+U_{i}
$$

dimana $U M K M$ adalah Usaha mikro, kecil, dan menengah, $P D B$ adalah Produk domsetik bruto, $K M K$ adalah Kredit modal kerja, $A K$ adalah Angkatan 
‘!!

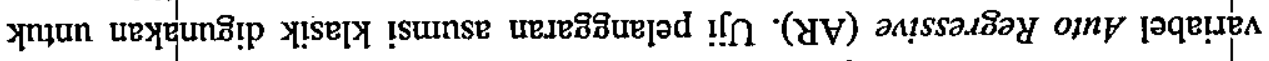

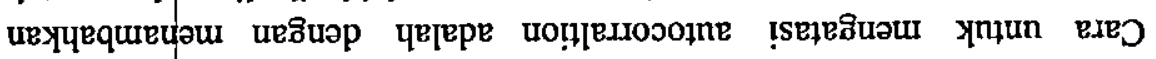

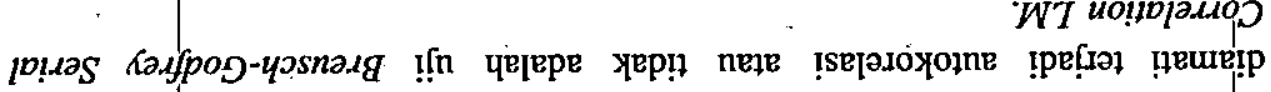

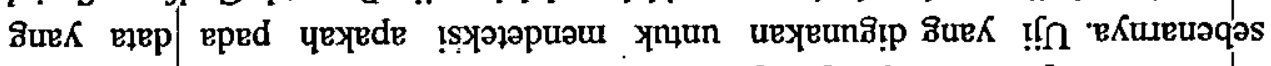

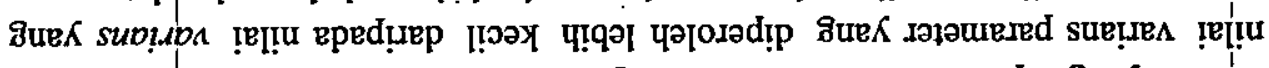

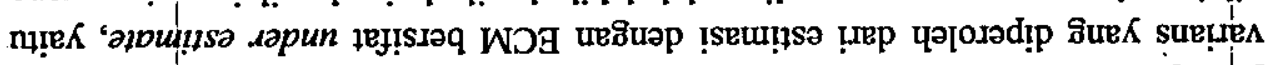
n!̣e иочрp

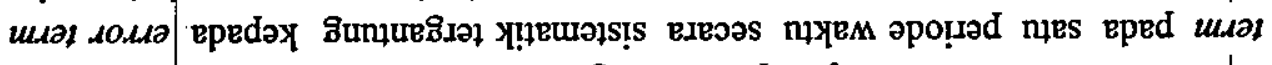

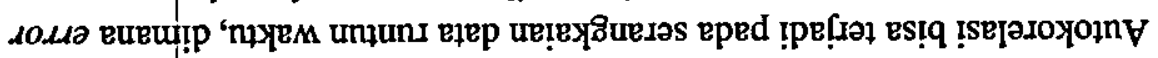

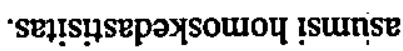

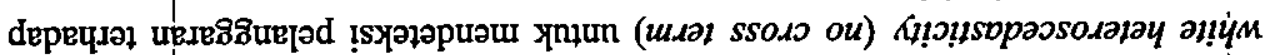

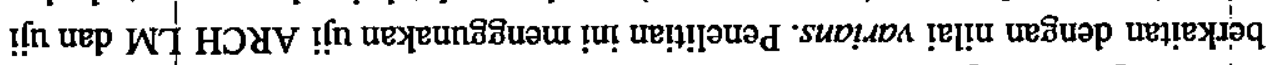

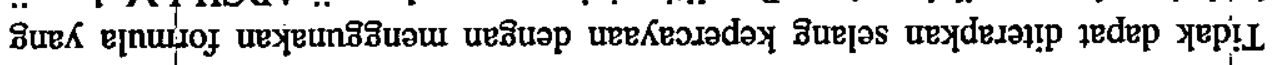

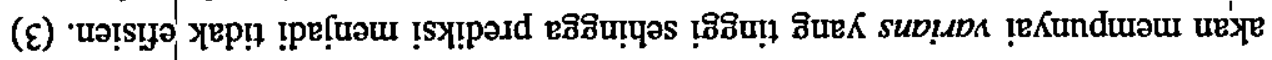

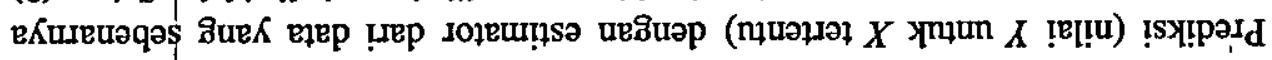

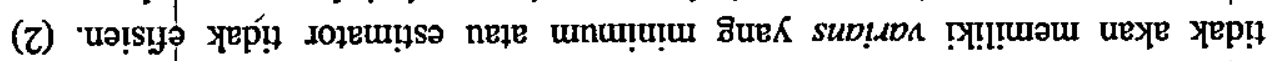

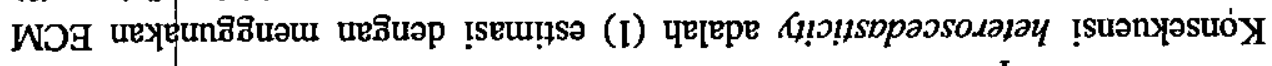
-oulsopasso,

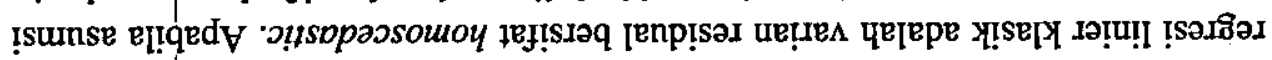

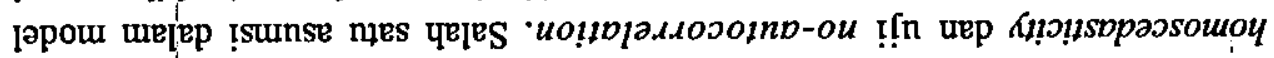

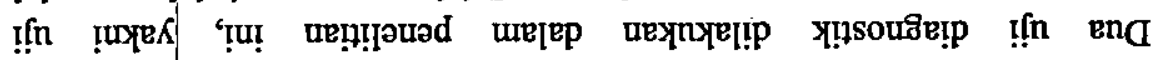

JPpow भ!ฺsouธิย!ส !!ก

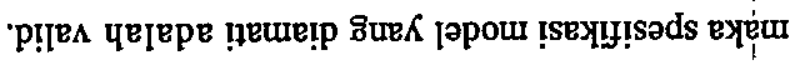

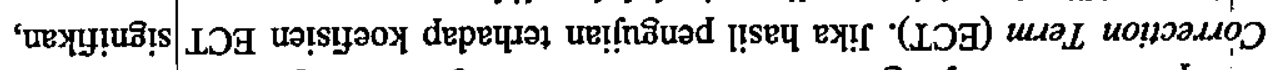

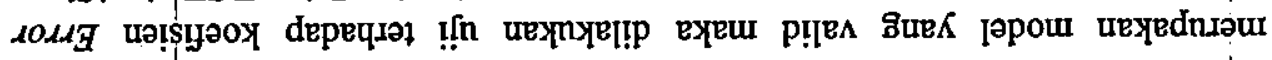

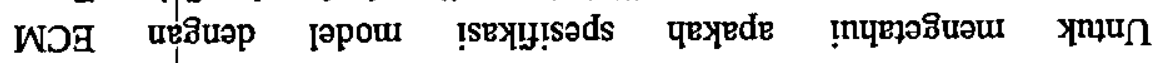

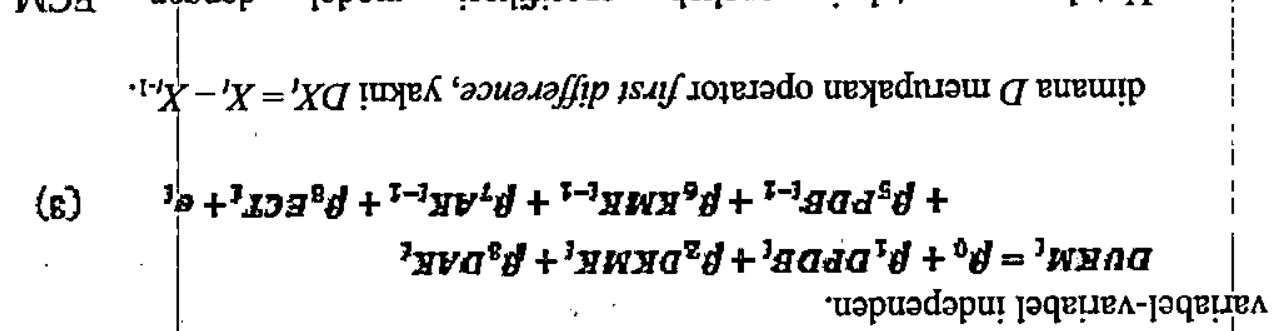

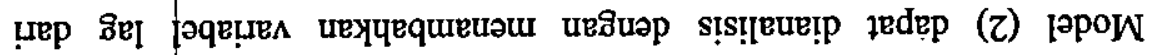

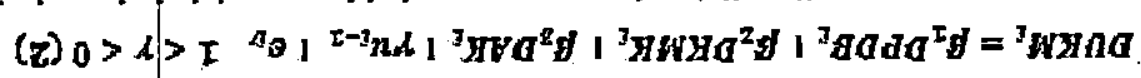

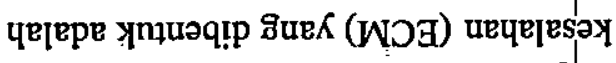

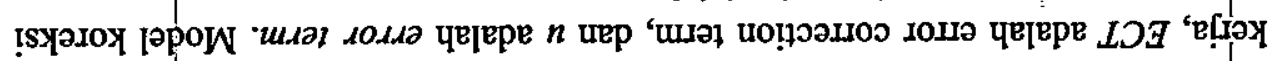

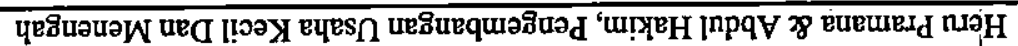




\section{Analisis}

\section{Unit Root Tets}

Untuk melihat stasioneritas data dengan unit root test, peneltian ini menggunakan uji ADF (augmented Dickey Fuller test). Berdasarkan hasil uji ADF in-level, diketahui bahwa semua variabel adalah stsioner kecuali PDB. Keadaan ini menunjukkan bahwa model yang digunakan pada penelitian ini belum memenuhi syarat untuk diestimasi dengan menggunakan metode ECM, karena ada salah satu variabel yang tidak stasioner in-level.

Tabel 2.

Hasil Uji Unit Root in-level

\begin{tabular}{lcccccc}
\hline \multirow{2}{*}{ VariabelNilai ADF } & \multicolumn{4}{c}{ Nilai Kritis MacKinnon } & \multirow{2}{*}{ Prob } & \multirow{2}{*}{ Keterangan } \\
\cline { 2 - 5 } & & $1 \%$ & $5 \%$ & $10 \%$ & & \\
\hline UKM & -1.351144 & -3.770000 & -3.190000 & -2.890000 & - & Tidak Stasioner \\
PDB & 1.346008 & -3.770000 & -3.190000 & -2.890000 & - & Tidak Stasioner \\
KMK & -0.416924 & -3.808546 & -3.020686 & -2.650413 & 0.8883 & Tidak Stasioner \\
AK & -1.530411 & -4.498307 & -3.658446 & -3.268973 & 0.7837 & Tidak Stasioner \\
\hline
\end{tabular}

Note: UKM dan PDB menggunakan uji DF, karena uji ADF menghasilkan koefisien UKMt-1 dan PDBt-1 yang positif.

Tabel 3.

Hasil Uji Unit Root in First Difference

\begin{tabular}{|c|c|c|c|c|c|c|}
\hline \multirow{2}{*}{ Variabel } & \multirow{2}{*}{ Nilai ADF } & \multicolumn{3}{|c|}{ Nilai Kritis MacKinnon } & \multirow{2}{*}{\multicolumn{2}{|c|}{ Prob Keterangan }} \\
\hline & & $1 \%$ & $5 \%$ & $10 \%$ & & \\
\hline$\overline{\mathrm{UKM}}$ & -3.352087 & -4.532598 & -3.673616 & 3.277364 & 0.0881 & Stasioner* \\
\hline DB & -3.754382 & -3.770000 & -3.190000 & -2.890000 & - & Stasioner \\
\hline $\mathrm{KMK}$ & -5.560884 & -4.532598 & -3.673616 & -3.277364 & 0.0095 & Stasioner \\
\hline $\mathrm{AKJ}_{\mathrm{i}}$ & -4.392584 & -4.532598 & -3.673616 & -3.277364 & 0.0131 & Stasioner \\
\hline
\end{tabular}

Note: PDB menggunakan uji DF, karena uji ADF menghasilkan koefisien PDBt-1 yang positif. * Stasioner dalam tingkat signifikansi $10 \%$.

Dari hasil uji yang diperlihatkan pada Tabel 2, maka perlu dilanjutkan dengan uji akar unit pada first difference. Uji ini dilakukan sebagai konsekuensi dari tidak terpenuhinya asumsi stasioneritas pada derajat nol atau $I(0)$. Hasil uji first difference dapat diketahui bahwa semua variabel. yang digunakan dalam model stasioner pada derajat integrasi satu aiau I(1), ditunjukkan dengan nilai statistik ADF yang lebih kecil dari nilai kritis pada tingkat kepercayaan sepuluh persen pada semua variabel, seperti pada Tabel 3. 


\section{Cointegration Test}

Syarat yang dibutuhkan untuk menunjukkan bahwa diantara variabelvariabel yang diteliti berkointegrasi adalah dengan melihat perilaku residual dari regresi persamaan yang digunakan, dimana residualnya harus stasioner. Hasil uji stasioneritas terhadap residual regresinya dapat dilihat pada Tabel 4. Dari tabel tersebut dapat kita lihat bahwa meskipun tidka signifikan pada tingkat $5 \%$, tetapi signifikan pada tingkat $6.5 \%$, yang dapat kita simpulkan bahwa ada kointegrasi dalam empat variabel tersebut.

$$
U K M_{1}=9657522-0.101 K A_{t}+0.787 K M K_{t}+2.925+U_{t}
$$

Uji akar unit terhadap residual persamaan regresi di atas menunjukkan bahwa nilai statistik adalah -1.879 dengan probabilitas 0.066 . Dengan demikian bisa dikatakan adanya kointegrasi dengan tingkat signifikansi $6.6 \%$.

\section{Error Correction Model}

Hasil analisis dengan model ECM bisa diringkas dalama Tabel 4. Dari sini dapat kita lihat bahwa tabel estimasi model dinamis ECM dapat diperoleh fungsi regresi OLS sebagai berikut :

Tabel 4.

Hasil Uji ECM

\begin{tabular}{lrr|l}
\hline Variabel & Coefficient & t-Statistic & Prob. \\
\hline C & 7176320. & 1.947866 & 0.0752 \\
DPDB & 0.002266 & 2.567449 & 0.0247 \\
DKMK & 6.922914 & 5.486694 & 0.0001 \\
DAK & -0.051871 & -1.306873 & 0.2157 \\
PDB(-1) & -1.016163 & -3.576924 & 0.0038 \\
KMK(-1) & 6.873201 & 3.596104 & 0.0037 \\
AK(-1) & -1.097591 & -3.678355 & 0.0032 \\
ECT & 1.018317 & 3.574942 & 0.0038 \\
\hline i & & &
\end{tabular}

Dimana $D$ merupakan operator first difference $\left(D X_{t}=X_{t}-X_{t-1}\right)$, dan $X(-1)=X_{t-1}$. Error correction term dirumuskan sebagai:

$$
E C T=P D B_{t-1}+K M K_{t-1}+A K J_{t-1}-U K M_{t-1}
$$

Dari hasil perhitungan di atas didapat nilai variabel ECM, dimana ECT dijadikan indikator dalam penentuan signifikansi model baik atau tidak, melalui tingkat signifikansi koefisien koreksi kesalahan. Jika variabel ECT signifikan pada tingkat signifikan 10 persen dan menunujukan tanda positif, maka spesifikasi model sudah valid dan dapat menjelaskan variasi variabel tak bebas. Hasil dari perhitungan diatas adalah tingkat signifikansi ECT menunujukkan angka 0.0038, signifikan pada $\alpha=0.38$ persen. 
Besarnya koefisien jangka pendek dari masing-masing variabel independen ditunjukkan oleh koefisien regresi dari masing-masing variabel independen yakni diperoleh dengan rumus $\left(b_{1}+b_{2}\right) / b_{1}$ dimana $b_{1}=$ koefisien regresi dari variabel independen yang mengandung $\operatorname{lag}_{\mathrm{t}-\mathrm{l}} \quad b_{\mathrm{t}}=$ koefisien regresi ECT. S̄edangkan koefisien regresi jangka panjang diperoleh dengan melakukan simulasi dari regresi ECM volume ekspor yaitu:

$$
\begin{array}{lll}
\text { Konstanta } & : & \beta_{0} / \beta_{7}=7176320 / 1.018317=7047235.8 \\
P D B & : & \left(\beta_{1}+\beta_{7}\right) / \beta_{7}=(0.002266+1.018317) / 1.018317=1.0022252 \\
K M K & : & \left(\beta_{2}+\beta_{7}\right) / \beta_{7}=(6.922914+1.018317) / 1.018317=7.7983879 \\
A K & : & \left(\beta_{3}+\beta_{7}\right) / \beta_{7}=(-0.051871+1.018317) / 1.018317=-1.050938
\end{array}
$$

$P D B_{t-1}, K M K_{t-1}, A K_{t-1}$, merupakan variabel-variabel yang menunjukkan parameter jangka pendek, sedangkan koefisien-koefisiennya menunjukkan besarnya pengaruh yang dilakukan pada penyesuaian variabel dependen terhadap perubahan variabel independen dalam jangka pendek. $P D B, K M K$, dan $A K$ dmerupakan variabel jangka panjang, hal ini berarti jika ECT signifikan pada $10 \%$, maka ada hubungan antara ECM dengan uji kointegrasi, sehingga koefisien regresi jangka panjang merupakan besarnya kekuatan pengaruh variabel dependen oleh perubahan pada variabel independen dalam jangka panjang.

Dari hasil olah data kita dapatkan bahwa $P D B_{t-1}$ signifikan dengan probabilats 0.0038 sehingga dalam jangka pendek berpengaruh terhadap total jumlah UMKM di Indonesia. $K M K_{t-1}$ signifikan pada tingkat 0.0037 sehingga dalam jangka pendek, kredit model kerja berpengaruh terhadap total jumlah UMKM di Indonesia. $A K_{t-1}$ signifikan pada tingkat 0.0032 sehingga dalam jangka pendek, angkatan kerja berpengaruh terhadap total jumlah UMKM di Indonesia

$P D B$ signifikan pada tingkat 0.0247 sehingga dalam jangka panjang, $P D B$ berpengaruh terhadap total jumlah $U M K M$ di Indonesia. Variabel $K M K$ signifikan pada tingkat 0.0001 sehingga dalam jangka panjang, kredit modal kerja berpengaruh terhadap total jumlah $U M K M$ di Indonesia. Probabilitas variabel $A K$ adalah 0.2157 sehingga dalam jangka panjang, $P D B$ tidak berpengaruh (dalam tingkat signifikansi $5 \%$ ) terhadap total jumlah $U M K M$ di Indonesia.

Dari hasil pengolahan data diperoleh nilai $F$ hitung sebesar 162.7885 dengan probabilitas 0.0000 . Dengan demikian dapat kita katakan bahwa secara bersama-sama, baik dalam jangka pendek maupun panjang, variabel-variabel PDB, kredit modal kerja yang disediakan perbankan, dan angkatan kerja mempunyai pengaruh yang signifikan terhadap total jumlah $U M K M$ di Indonesia.

\section{Uji Diagnostik Model}

Berdasarkan hasil penelitian yang dimanifestasikan dalam persamaan regresi yang digunakan, perlu dikaji apakah hasil tersebut dapat digunakan untuk 
analisis lebih lanjut. Dengan kata lain, apakah hasil regresi telah memenuhi kaidah best linear unbiased estimator (BLUE) ataukah tidak. Dalam hal ini, kita perlu menguji apakah model yang dibangun melanggar asumsi klasik dalam metode regresi ECM ataukah tidak. Dua asumsi penting yang akan dianalisis adalah asumsi homoskedastisitas dan no-autocorrelation.

Untuk mendeteksi keberadaan heteroskedasitas, penelitian ini menggunakan uji white dengan distribusi $\chi^{2}$. Dengan $\alpha=10 \%$ dan derajat bebas 13 , nilai $\chi^{2}$ - kritis adalah 29.8195. Nilai $\chi^{2}$ - uji dari hasil regresi adalah 18.78466 , sehingga kita bisa tidak menolak $H_{0}$ bahwa residual adalah homoskedastik. Konfirmasi lain bisa didapatkan dari nilai probabilitas yang dilaporkan Eviews, yakni sebesar 0.129933 , yang berarti bahwa dengan tingkat signifikasi $10 \%$ sekalipun kita tidak bisa menolak $H_{0}$.

Tabel 5.

Hasil Uji Heteroskedastasitas.

White Heteroskedasticity Test:

\begin{tabular}{llll}
\hline \hline F-statistic & 7.133682 & Prob. F(13,6) & 0.012013 \\
.Obs*R-squared & 18.78466 & Prob. Chi-Square(13) & 0.129933 \\
\hline
\end{tabular}

\section{5. ' Uji Autokorelasi}

Autokorelasi menunjukkan korelasi diantara anggota serangkaian observasi yang diurutkan menurut waktu atau ruang. Untuk itu maka dilakukan uji Lagrange Multiplier ( LM) yaitu memasukkan variabel kelambanan (Lag).

Tabel 6.

Hasil Uji Autokorelasi Dengan Metode LM Pada Lag 2

Breusch-Godfrey Serial Correlation LM Test:

\begin{tabular}{llll|}
\hline F-statistic & 0.219249 & Prob. F(2,5) & 0.810453 \\
Obs*R-squared & 1.451311 & Prob. Chi-Square(2) & 0.484007 \\
\hline & & \\
\hline
\end{tabular}
Godfrey). Metode ini didasarkan pada nilai $F$ dan Obs*R-Squared, dimana jika nilai probilitas dari $O b s^{*} \mathrm{R}-S q u a r e d$ melebihi tingkat kepercayaan, maka $H_{0}$ diterima, artinya tidak ada masalah autokorelasi. Uji LM test ini bias dikatakan sebagai uji autokorelasi paling akurat. 
Saat melakukan uji ini langkah pertama adalah memasukkan lag nya, dari hasil uji autokorelasi Serial Corelation LM Test Lag 2 seperti terlampir dalam olah data diatas, terlihat bahwa $F_{u j i}$ sebesar 0.219249 dengan nilai probabilitas 0.810453 . Sedangkan nilai Obs*R Squared tidak signifikan pada alfa $10 \%$ dengan kata lain nilai chi-squared hitung lebih kecil dari nilai kritis artinya tidak mengandung unsur autokorelasi.

\section{Penutup}

Dari hasil analisis secara deskriptif, penelitian ini menemukan bahwa kondisi perekonomian Indonesia sangat dipengaruhi oleh UKM sehingga pemerintah bersama lembaga keungan dan instansi terkait perlu secara bersamasama dan terintegrasi meningkatkan jumlah pertumbuhan UKM di Indonesia. Berdasarkan hasil analisis regresi yang telah dilakukan, dapat diambil kesimpulan bahwa PDB, kredit modal kerja dan angkatan kerja berpengaruh terhadap jumlah UMKM, baik dalam jangka pendek maupun jangka panjang. 


\section{DAFTAR PUSTAKA}

Badan Pusat Statistik, Statstik Indonesia, Beberapa tahun terbitan.

Engle, R.F. dan C.W.J. Granger (1987), "Co-integration and Error Correction: Representation, Estimation, and Tèsting," Econometrica, 55, 251-276.

Hafsah, M.J. (2004), "Upaya Pengembangan Usaha Kecil dan Menengah (UKM)," Infokop, 25, 40-44.

Herlambang (2001), Ekonomi Makro: teori analisis dan kebijakan. Jakarta: Ghalia Indonesia.

Lestari, S. (2007), "Strategi Pengembangan dan Pembiayaan UKM," Deputi Bidang Pengkajian Sumberdaya UMKM.

Munizu, M. (2010), "Pengaruh Faktor-faktor Eksternal dan Internal terhadap Kinerja Usaha Mikro dan Kecil (UMK) di Sulawesi Selatan," Jurnal Manajemen dan Kewirasuhaan, Fakultas Ekonomi Universitas Hasanuddin, 12(1), 33-41:

Permadi, I.M.R. (2009), Pengaruh Total Kredit, PDB, dan Tingkat Suku Bunga terhadap Perkembangan Jumlah Unit Usaha Berskala Kecil dan Menengah (UKM), Skripsi Sarjana, Departemen Ilmu Ekonomi, Fakultas Ekonomi dan Manajemen, Institu Pertanian Bogor.

Sakernas (2007), Partisipasi Angkatan Kerja, tersedia di http:// www.menegpp .go.id. Diunduh April 2011.

Sebstad, J. dan G. Chen (1996), "Overview of Studies on the Impact of Microenterprise Credit," Assessing the Impact of Microenterprise Services (AIMS), Management Systems International, bisa diakses di http://pdf.usaid.gov/pdf_docs/PNABZ074.pdf.

Sriyana, J. (2010), "Strategi Pengenbamgan Usaha Kecil dan Menengah (UKM): Studi Kasus di Kabupaten Bantul," Simposium Nasional 2010: Menuju Purworejo Dinamis dan Kreatif, hal. 79-103.

Tejasari, M. (2008), "Peranan Sektor Usaha Kecil dan Menengah dalam Penyerapan Tenaga Kerja dan Pertumbuhan Ekonomi di Indonesia," Departemen Ilmu Ekonomi Fakultas Ekonomi dan Manajemen Bogor.

Tim Studi Departemen Keuangan RI (2011), Potensi Perusahaan UKM untuk Go Public, Departemen Keuangan Republik Indonesia, Badan Pengawas Pasar Modal dan Lembaga Keuangan tahun Anggaran 2011.

UU No. 20 Tahun 2008 tentang Usaha Mikro, Kecil, dan Menengah, Jakarta.

Wadud, M. (2004), "Pengaruh Variabel-variabel Ekonomi terhadap Pertumbuhan

Ekonomi Kabupaten Musi Banyuasin, Forderna, 4(1), 661-678. 